\title{
Keragaan Permesinan dan Keteguhan Rekat Kayu Jati Cepat Tumbuh Terdensifikasi
}

\section{(Machining Performance and Bonding Quality of Densified Faster-Grown Teakwood)}

\author{
Herianto Siahaan, Imam Wahyudi ${ }^{\star}$
}

(Diterima Maret 2020/Disetujui Juli 2020)

\begin{abstract}
ABSTRAK
Penelitian ini bertujuan untuk menganalisis keragaan sifat dan mutu proses permesinan serta keteguhan rekat kayu terdensifikasi dan membandingkannya dengan yang terdapat pada kayu kontrol (tanpa perlakuan) dan yang hanya diawetkan. Contoh uji yang digunakan adalah kayu jati cepat tumbuh dari tegakan hutan tanaman umur 5 tahun di Kecamatan Ciampea, Bogor. Sifat dan mutu proses permesinan dinilai langsung pada saat dikerjakan oleh praktisi berpengalaman, sedangkan keteguhan rekat diwakili oleh nilai keteguhan gesernya. Hasil penelitian menunjukkan densifikasi mampu memperbaiki keragaan permesinan dan meningkatkan nilai keteguhan rekat kayu. Dibandingkan dengan kayu kontrol dan kayu yang hanya diawetkan, kayu yang terdensifikasi tetap mudah dikerjakan dengan permukaan yang lebih halus dan memiliki warna yang menyerupai warna kayu jati tua; sedangkan nilai keteguhan rekatnya meningkat 18,79 dan $\mathbf{2 6 , 8 6 \%}$. Hasil analytic hierarchy process (AHP) membuktikan kayu jati terdensifikasi lebih cocok dijadikan bahan baku mebel atau furniture daripada kayu kontrol maupun kayu yang hanya diawetkan karena memiliki keragaan permesinan, penampilan, warna, dan keteguhan rekat yang lebih baik.
\end{abstract}

Kata kunci: AHP, densifikasi, jati cepat tumbuh, keteguhan rekat, sifat permesinan

\section{ABSTRACT}

The objective of this study was to analyze machining performance (characteristic and quality), as well as bonding quality of densified wood, and then compared to those of un-treated (control) wood and boron-treated wood. Characteristic and quality of machining properties were directly evaluated by qualified technician during processing, while bonding quality was evaluated through its shear strength. The results showed that densification employed was able to improve machining performance and bonding quality of the 5-year-old faster-grown teakwood. Compared to control wood and boron-treated wood, machining performances of densified teakwood are greater, while bonding quality increased by 18.79 and $26.86 \%$, respectively. The surface became much fine and even, and has similar colour to older teakwood. Analysis hierarchy process (AHP) proves that densified teakwood is the best raw material for furniture manufacturing since its machining performances, appearance, colour, and bonding quality are better either than control wood or boron-treated wood.

Keywords: AHP, bonding quality, densification, faster-grown teakwood, machining performance

\section{PENDAHULUAN}

Kayu merupakan sumber daya terbarukan yang telah sejak lama digunakan sebagai bahan baku di berbagai industri perkayuan. Meskipun ketersediaannya semakin terbatas dan sulit diperoleh, permintaan akan kayu jati (Tectona grandis) untuk industri mebel cenderung meningkat dari tahun ke tahun. Tidaklah mengherankan bila akhir-akhir ini berbagai jenis bibit jati cepat tumbuh banyak dikembangkan dan ditanam, dan kayunya pun sudah diperdagangkan.

Kayu jati cepat tumbuh pada umumnya diperoleh dari hutan tanaman (Achdiawan \& Puntodewo 2011). Di beberapa daerah di tanah air, kayu-kayu tersebut berasal dari tegakan yang berumur $<10$ tahun dengan

Departemen Hasil Hutan, Fakultas Kehutanan dan Lingkungan, Institut Pertanian Bogor, Kampus IPB Darmaga, Bogor 16680

*Penulis Korespondensi: Email: imyudarw16@yahoo.com diameter batang yang sudah layak jual $(>20 \mathrm{~cm})$. Menurut Yovi et al. (2013), 90\% industri mebel di Jepara sudah menggunakan kayu jati cepat tumbuh hasil hutan tanaman, meski diketahui mutu kayu jati yang demikian lebih inferior dibandingkan dengan mutu kayu jati tua (>40 tahun), khususnya dari segi kekuatan, keawetan, dan kestabilan dimensi (Wahyudi et al. 2014).

Untuk menghindari penurunan mutu mebel yang akan dihasilkan, karakteristik kayu jati hasil hutan tanaman perlu ditingkatkan. Salah satunya dengan mengawetkan kayu dan langsung dilanjutkan dengan proses pemadatan pada suhu dan tekanan tertentu (densifikasi) sebelum diproses lebih lanjut. Berdasarkan hasil penelitian terdahulu diketahui bahwa kekuatan, kestabilan dimensi, dan keawetan kayu jati terdensifikasi meningkat secara signifikan dibandingkan dengan kayu jati kontrol atau kayu jati tanpa perlakuan (Nestri 2014) maupun kayu jati yang hanya 
diawetkan (Danuwihardi 2015). Akan tetapi, sifat dan mutu proses permesinan serta keteguhan rekatnya belum pernah diteliti.

Berdasarkan hal tersebut, penelitian ini bertujuan untuk menganalisis keragaan permesinan (sifat dan mutu proses) serta keteguhan rekat kayu jati cepat tumbuh yang terdensifikasi dan membandingkannya dengan yang terdapat pada kayu jati kontrol maupun kayu jati yang hanya diawetkan. Untuk menentukan hasil terbaik dari ketiga macam perlakuan yang diaplikasikan, dilakukan juga analisis hirearchy process (AHP).

\section{METODE PENELITIAN}

\section{Bahan dan Alat}

Bahan utama yang digunakan adalah kayu jati berupa log dengan diameter rata-rata $25,20 \mathrm{~cm}$ dan panjang $90 \mathrm{~cm}$, larutan pengawet boron berkonsentrasi $2,0 \%$ yang merupakan campuran antara boraks $\left(\mathrm{Na}_{2} \mathrm{~B}_{4} \mathrm{O}_{7} .10 \mathrm{H}_{2} \mathrm{O}\right)$ dan natrium karbonat $\left(\mathrm{Na}_{2} \mathrm{CO}_{3}\right)$ dengan perbandingan 2:1, perekat isosianat, dan air destilata. Log berasal dari bagian pangkal batang yang diekstrak dari tegakan hutan tanaman jati umur 5 tahun milik masyarakat di Kecamatan Ciampea, Kabupaten Bogor. Jumlah pohon yang ditebang sebanyak lima batang yang sehat dan lurus.

Alat yang digunakan terdiri atas jangka sorong, moisture meter, waterbath, timbangan, kempa panas, kempa dingin (klem), kompor, drum atau tempat merebus, gergaji mesin, mesin planer, mesin bor, dan mesin moulding.

\section{Persiapan Bahan}

Kelima batang log dibelah menjadi papan setebal 5 $\mathrm{cm}$ lalu dikeringudarakan selama 60 hari hingga kadar air (KA) papan $\pm 15 \%$. Papan tangensial kemudian diserut untuk membuat contoh uji dengan dua ukuran ketebalan, yakni 2 dan $4 \mathrm{~cm}$. Hasil serutan kemudian dipilah dan hanya bagian teras yang dijadikan contoh uji. Contoh uji kontrol dan yang hanya diawetkan masing-masing berukuran $90 \mathrm{~cm}$ (panjang) $\times 7 \mathrm{~cm}$ (lebar) $\times 2 \mathrm{~cm}$ (tebal), sedangkan contoh uji densifikasi (diawetkan dan dipadatkan) berukuran $90 \mathrm{~cm}$ (panjang) $\times 7 \mathrm{~cm}$ (lebar) $\times 4 \mathrm{~cm}$ (tebal). Masing-masing perlakuan dibuat 10 ulangan secara acak tanpa mempertimbangkan asal pohon. Sebelum diuji, contoh uji kontrol dimasukkan ke dalam plastik tertutup untuk mempertahankan KAnya.

\section{Proses Pengawetan}

Contoh uji yang digunakan adalah contoh uji perlakuan pengawetan dan perlakuan densifikasi. Proses pengawetan dilakukan bersama-sama secara rendaman panas $\left(80^{\circ} \mathrm{C}\right)$ selama 5 jam mengikuti AWPA A3-77 (1997) yang dimodifikasi. Bahan pengawet yang digunakan adalah boron berkon- sentrasi 2,0\% (Nestri 2014; Danuwihardi 2015). Setelah diawetkan, tiga buah contoh uji dari masingmasing perlakuan digunakan untuk menghitung nilai retensi dan penetrasi bahan pengawet. Tujuh buah contoh uji perlakuan pengawetan langsung dikeringudarakan selama 14 hari, sedangkan tujuh buah contoh uji perlakuan densifikasi langsung dipadatkan.

\section{Proses Densifikasi (Pengawetan dan Pemadatan)}

Setelah diawetkan sebagaimana yang dijelaskan di atas, ketujuh contoh uji langsung dipadatkan menggunakan mesin kempa panas $\left(150^{\circ} \mathrm{C}\right)$ dengan tekanan $20 \mathrm{MPa}$ selama 15 menit secara perlahanlahan dengan target pengurangan tebal sebesar 50\% dari ukuran awal (Nestri 2014; Danuwihardi 2015). Setelah mencapai target, contoh uji di-equalizing dengan tetap berada di bawah tekanan semalaman, dengan kondisi mesin "off". Sebelum diuji, papan dikeringudarakan selama 14 hari. Target pengurangan tebal $50 \%$ ditetapkan berdasarkan hasil penelitian pendahuluan (Wahyudi et al. 2014).

\section{Perhitungan Retensi dan Penetrasi}

Pengujian retensi dan penetrasi diawali dengan membuat dua macam larutan pereaksi, yaitu A dan B. Larutan pereaksi $A$ terdiri atas $10 \mathrm{~g}$ ekstrak bubuk kunyit dalam $100 \mathrm{~mL}$ alkohol, sedangkan larutan $\mathrm{B}$ terdiri atas $80 \mathrm{~mL}$ alkohol dan $20 \mathrm{~mL}$ asam klorida $(\mathrm{HCl})$ yang dijenuhkan dengan asam salisilat.

Setelah diawetkan, contoh uji ditiriskan, lalu ditimbang dan dikeringudarakan. Setelah kering udara, contoh uji dipotong dua tepat di bagian tengah ukuran panjang sampel. Pereaksi A kemudian disemprotkan ke bidang potong, dan setelah 3-5 menit baru disemprotkan larutan B. Perembesan bahan pengawet ke dalam kayu ditandai dengan adanya perubahan warna pada bidang potong, yaitu menjadi merah atau jingga. Penetrasi diukur dengan membandingkan luas permukaan contoh uji yang ditembus bahan pengawet dengan luas total permukaan contoh uji dan mengukur dalam perembesan bahan pengawet ke dalam kayu; sedangkan retensi bahan pengawet dihitung menggunakan persamaan:

$$
\text { Retensi }\left(\mathrm{kg} / \mathrm{m}^{3}\right)=\left[\left(\mathrm{B}_{\mathrm{a}}-\mathrm{B}_{0}\right) / \mathrm{V}\right] \times \mathrm{C}
$$

\section{Keterangan:}

$\mathrm{B}_{\mathrm{a}} \quad=$ Bobot contoh uji sesudah diawetkan $(\mathrm{kg})$

$\mathrm{B}_{0}=$ Bobot contoh uji sebelum diawetkan $(\mathrm{kg})$

$\mathrm{V}=$ Volume contoh uji $\left(\mathrm{m}^{3}\right)$

C = Konsentrasi larutan bahan pengawet

\section{Proses Permesinan}

Contoh uji kontrol $(n=10)$, yang hanya diawetkan $(n=7)$, dan yang didensifikasi $(n=7)$ selanjutnya "dikerjakan" dengan mesin untuk menilai keragaan pada saat digergaji, dibor, diserut, diampelas, dan 
dibentuk. Penilaian dilakukan melalui praktik langsung oleh tukang kayu professional (Tabel 1).

\section{Keteguhan rekat}

Nilai keteguhan rekat didekati melalui nilai keteguhan geser rekat. Pengujian dilakukan mengacu pada JAS 234 (2003). Contoh uji berukuran $100 \mathrm{~mm} x$ $25 \mathrm{~mm} \times 10 \mathrm{~mm}$ (Gambar 1) dibuat dari potongan sisa contoh uji permesinan. Masing-masing perlakuan diwakili oleh lima buah contoh uji (panel glulam dua lapis). Perekat yang digunakan adalah isosianat dengan perbandingan perekat dan hardener 20:3. Perekatan dilakukan dengan bantuan kempa dingin selama 1 hari dan kondisioning selama 14 hari.

\section{Pemilihan Bahan Baku}

Pemilihan bahan baku terbaik dari ketiga macam perlakuan yang diterapkan dilakukan menggunakan analytic hierarchy process (AHP) (Saaty 1980). Nilai indeks randomnya ditunjukkan pada Tabel 2.

Tabel 1 Skoring keragaan proses permesinan

\begin{tabular}{cc}
\hline Skor & $\begin{array}{c}\text { Kemudahan kayu pada saat } \\
\text { dikerjakan*) }\end{array}$ \\
\hline 10 & Sangat sulit \\
6 & Sulit \\
3 & Sedang \\
1 & Mudah \\
0 & Sangat mudah \\
Keterangan: $^{*}=$ Untuk setiap proses
\end{tabular}

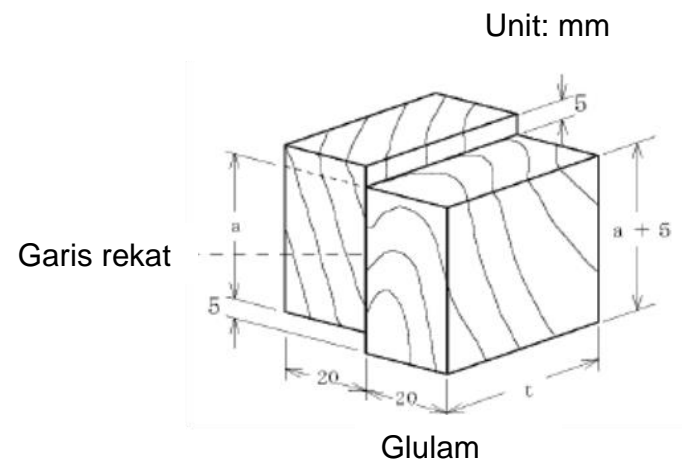

Gambar 1 Contoh uji keteguhan geser rekat.

Tabel 2 Nilai indeks random

\begin{tabular}{cc}
\hline $\mathrm{N}$ & $\mathrm{Rl}$ \\
1 & 0,00 \\
2 & 0,00 \\
3 & 0,58 \\
4 & 0,90 \\
5 & 1,12 \\
6 & 1,24 \\
7 & 1,32 \\
8 & 1,41 \\
9 & 1,45 \\
10 & 1,49 \\
\hline Keterangan: $\mathrm{N}=$ nilai (score) dan $\mathrm{R}=$ konstanta indeks \\
random.
\end{tabular}

\section{Analisis Data}

Data kuantitatif dianalisis menggunakan Microsoft Excel 2007 dan Minitab 17 Statistic Software for windows untuk memperoleh nilai rata-rata dan simpangan bakunya. Untuk mengetahui taraf signifikansi perbedaan perlakuan antara kontrol, kayu yang hanya diawetkan, dan yang didensifikasi pada sifat-sifat yang diteliti dilakukan pengujian beda ratarata dari dua sampel yang berpasangan (paired sample t-test) pada tingkat kepercayaan 95\% ( $\alpha=0,05)$. Kriteria pengujiannya adalah:

1) Jika nilai probability atau signifikansi atau p-value $<0,05$, maka perbedaan perlakuan memberikan pengaruh nyata.

2) Jika nilai probability atau signifikansi atau p-value $\geq 0,05$, maka perbedaan perlakuan tidak memberikan pengaruh nyata.

\section{HASIL DAN PEMBAHASAN}

\section{Retensi dan Penetrasi}

Hasil perhitungan menunjukkan rata-rata nilai retensi adalah $1,08 \mathrm{~kg} / \mathrm{m}^{3}$, sedangkan penetrasinya $56,80 \%$ atau sedalam $0,55 \mathrm{~cm}$ (Tabel 3). Nilai penetrasi yang diperoleh tergolong rendah, meski masuk ke dalam kategori moderately resistant sebagaimana dinyatakan oleh Smith dan Tamblyin (1970). Secara umum, retensi dan penetrasi yang dihasilkan juga lebih rendah dibandingkan dengan hasil Danuwihardi (2015). Perbedaan ini terkait dengan perbedaan ukuran contoh uji yang digunakan. Danuwihardi (2015) menggunakan contoh berukuran kecil (yakni panjang $45 \mathrm{~cm}$, sedangkan lebar dan tebalnya $2 \mathrm{~cm}$ ).

Proses pengawetan yang dilakukan dapat kan tidak memenuhi batas minimum sebagaimana ditentukan oleh SNI 03-5010.1-1999, yakni $12 \mathrm{~kg} / \mathrm{m}^{3}$. Hal ini diperkuat oleh hasil pengamatan bahwa hanya sedikit boron yang masuk ke dalam kayu, dan tidak semua rongga diisi oleh boron (Gambar 2).

\section{Sifat dan Mutu Proses Permesinan}

Rata-rata keragaan proses permesinan kayu disajikan pada Tabel 4. Dari tabel tersebut diketahui bahwa kayu kontrol dan kayu yang hanya diawetkan meskipun lebih mudah dikerjakan namun kualitasnya lebih rendah dibandingkan dengan kayu yang terdensifikasi. Permukaan kayu kontrol dan kayu yang hanya diawetkan lebih kasar karena banyak ditemukan kehadiran serat berbulu dan serat terangkat. Pada kayu terpadatkan tidak dijumpai adanya patahan serat di bekas pemotongan dan pengeboran. Hal ini mengindikasikan bahwa sifat permesinan kayu terdensifikasi lebih baik dan mutu prosesnya lebih tinggi dibandingkan sifat dan mutu proses permesinan kayu kontrol maupun kayu yang hanya diawetkan. 
Tabel 3 Rata-rata retensi dan penetrasi bahan pengawet setelah kayu diawetkan

\begin{tabular}{|c|c|c|}
\hline Parameter & Rata-rata & Simpangan baku \\
\hline \multicolumn{3}{|l|}{ Retensi $\left(\mathrm{kg} / \mathrm{m}^{3}\right)$ : } \\
\hline Tebal $2 \mathrm{~cm}$ & 1,32 & 0,06 \\
\hline Tebal $4 \mathrm{~cm}$ & 0,84 & 0,05 \\
\hline Rata-rata & 1,08 & 0,26 \\
\hline \multicolumn{3}{|l|}{ Penetrasi $(\mathrm{cm})$ : } \\
\hline Tebal $2 \mathrm{~cm}$ & 0,55 & 0,05 \\
\hline Tebal $4 \mathrm{~cm}$ & 0,54 & 0,05 \\
\hline Rata-rata & 0,55 & 0,05 \\
\hline \multicolumn{3}{|l|}{ Penetrasi (\%): } \\
\hline Tebal $2 \mathrm{~cm}$ & 67,96 & 0,02 \\
\hline Tebal $4 \mathrm{~cm}$ & 45,63 & 0,03 \\
\hline Rata-rata & 56,80 & 0,12 \\
\hline
\end{tabular}
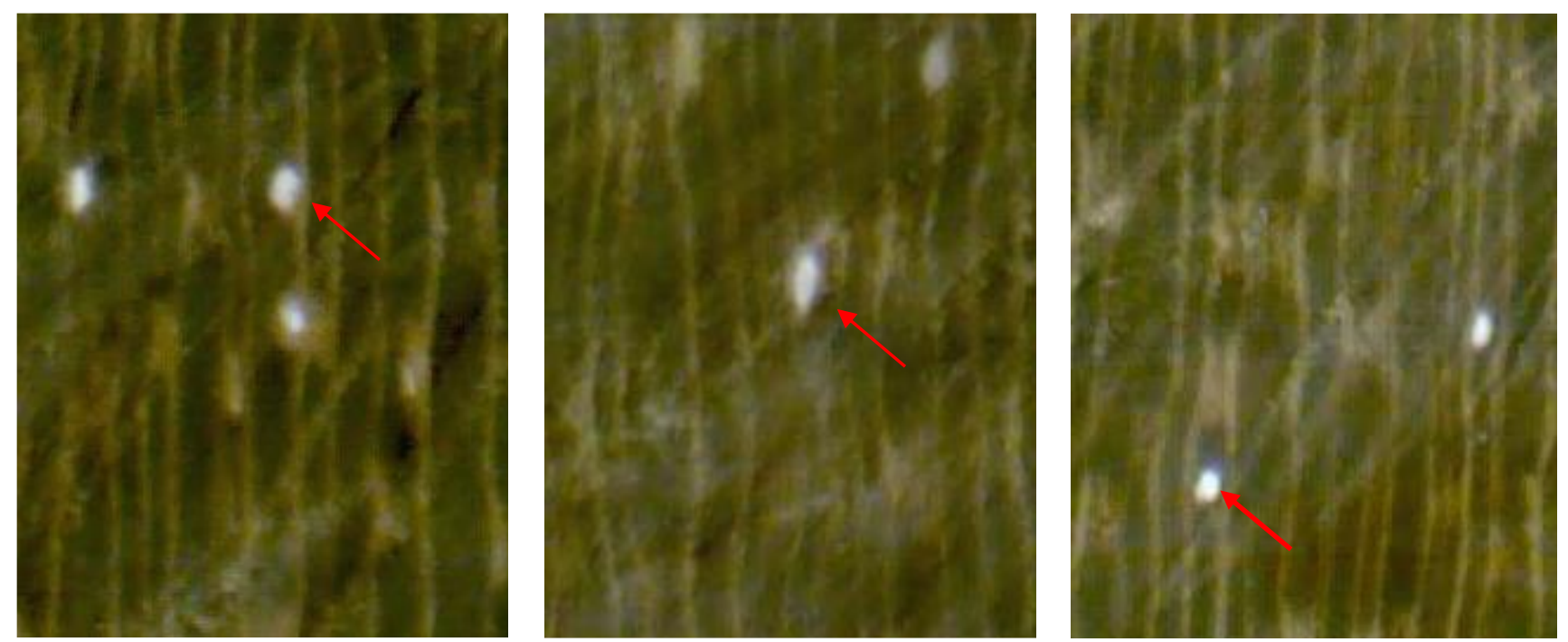

Gambar 2 Keberadaan boraks (tanda panah) dalam kayu jati yang terdensifikasi (penampang lintang, perbesaran 10X).

Tabel 4 Perbedaan sifat dan mutu proses permesinan di antara tiga perlakuan

\begin{tabular}{llcc}
\hline \multicolumn{1}{c}{ Parameter/variabel } & Kontrol & $\begin{array}{c}\text { Hanya } \\
\text { diawetkan }\end{array}$ & $\begin{array}{c}\text { Densifikasi } \\
\text { (Diawetkan dan dipadatkan) }\end{array}$ \\
\hline Dipotong & Mudah & Mudah & Sedang \\
Diserut & Mudah & Mudah & Mudah \\
Diampelas & Mudah & Mudah & Mudah \\
Dibentuk & Mudah & Mudah & Sedang \\
Dibor & Mudah & Mudah & Sedikit \\
Serat berbulu & Banyak & Banyak & Sedikit \\
Serat terangkat & Banyak & Banyak & Tidak ada \\
Serat patah & Ada & Ada & \\
\hline
\end{tabular}

\section{Keteguhan Rekat}

Rata-rata nilai keteguhan rekat disajikan pada Tabel 5. Dari Tabel 5 diketahui bahwa densifikasi mampu meningkatkan nilai keteguhan rekat, sedangkan kayu yang hanya diawetkan bahkan mengurangi nilai keteguhan rekatnya. Hasil analisis (Tabel 6) memperlihatkan bahwa densifikasi berpengaruh nyata pada nilai keteguhan rekat, sedangkan kayu yang hanya diawetkan tidak berpengaruh nyata. Dari Tabel 6 diketahui juga bahwa perlakuan hanya diawetkan tidak berpengaruh pada nilai keteguhan rekat, yang berarti sama dengan yang terdapat pada kayu kontrolnya. Sebaliknya, perlakuan densifikasi berpengaruh nyata pada kontrol dan berpengaruh sangat nyata pada kayu yang hanya diawetkan.

Menurut Blomberg (2006) dan Hill (2006), densifikasi mengakibatkan pemipihan sel-sel penyusun kayu. Hal ini dibuktikan dari hasil pengamatan penampang lintang contoh uji (Gambar 3). Pemipihan sel mengakibatkan rongga kayu berkurang dan kayu menjadi lebih padat sehingga meningkatkan kekuatan dan kestabilan dimensi kayu. Hal ini sesuai dengan hasil yang dilaporkan oleh Inoue et al. (1993); Sulistyono et al. (2003); Hasan \& Tatong (2005); Amin \& Dwianto (2006). Adanya panas turut berkontribusi pada penurunan sifat higroskopisitas kayu karena sebagian amorf dinding sel berubah menjadi kristalit. 
Tabel 5 Rata-rata keteguhan rekat pada masing-masing perlakuan

\begin{tabular}{|c|c|c|c|}
\hline $\begin{array}{c}\text { Parameter yang } \\
\text { diteliti }\end{array}$ & Perlakuan & Rata-rata & $\begin{array}{c}\text { Simpangan } \\
\text { baku }\end{array}$ \\
\hline $\begin{array}{l}\text { Keteguhan rekat } \\
\left(\mathrm{kg} / \mathrm{cm}^{2}\right)\end{array}$ & $\begin{array}{l}\text { Kontrol } \\
\text { Hanya diawetkan } \\
\text { Densifikasi (diawetkan dan dipadatkan) }\end{array}$ & $\begin{array}{l}68,58 \\
64,22 \\
81,47\end{array}$ & $\begin{array}{l}10,50 \\
15,36 \\
21,89\end{array}$ \\
\hline
\end{tabular}

Tabel 6 p-value perbandingan antar-perlakuan

\begin{tabular}{clcc}
\hline $\begin{array}{c}\text { Parameter yang } \\
\text { diteliti }\end{array}$ & \multicolumn{1}{c}{ Antar-perlakuan } & p-value & Sign. \\
\hline \multirow{3}{*}{ Keteguhan rekat } & Kontrol dan hanya diawetkan & 0,060 & tn \\
& Kontrol dan densifikasi & 0,040 & $*$ \\
& Hanya diawetkan dan densifikasi & 0,007 & $* \star$
\end{tabular}

Keterangan: $\mathrm{tn}=$ tidak nyata, ${ }^{*}=$ nyata pada $\alpha=0,05$, dan ${ }^{* *}=$ sangat nyata pada $\alpha=0,01$.
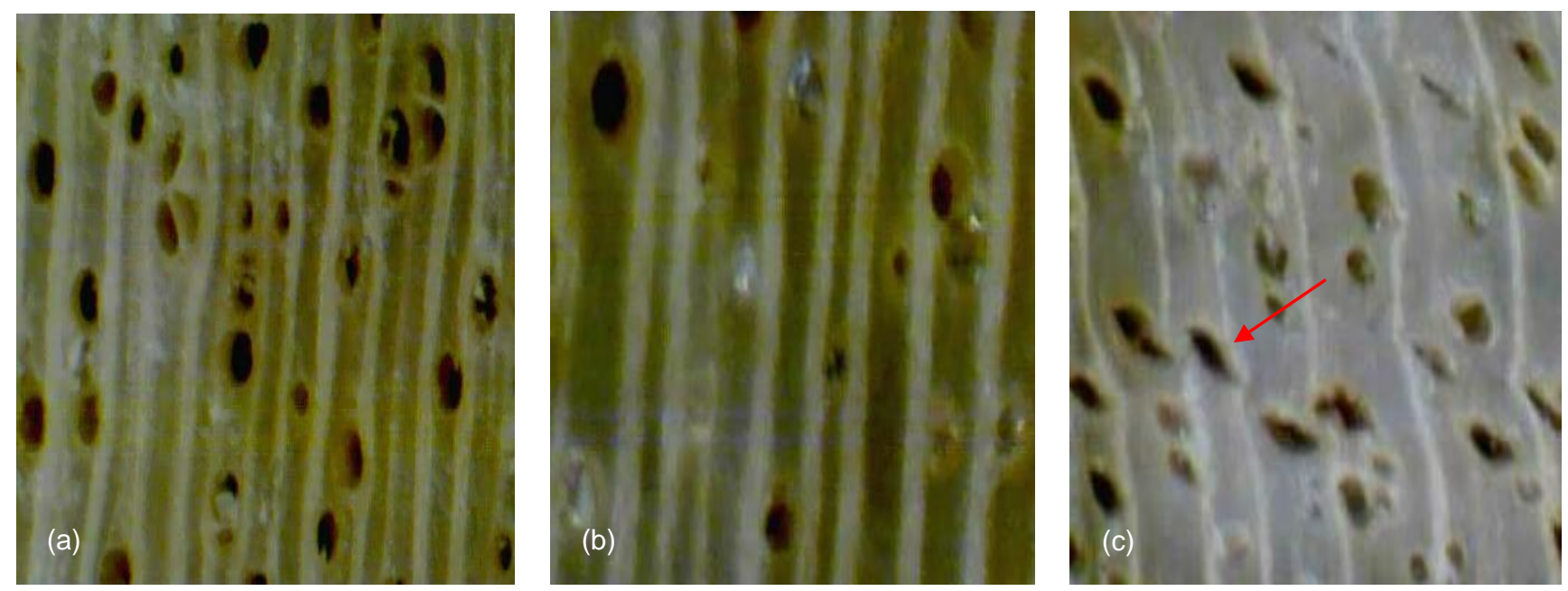

Gambar 3 Penampang lintang kayu jati cepat tumbuh: a) kontrol, b) hanya diawetkan, dan c) terdensifikasi (perbesaran 10X). Tanda panah menunjukkan rongga pori memipih.

Hasil penelitian menunjukkan bahwa dibandingkan dengan kontrol, rata-rata nilai keteguhan rekat kayu terpadatkan meningkat sebesar $18,79 \%$ (dari 68,58 menjadi $81,47 \mathrm{~kg} / \mathrm{cm}^{2}$ ), sedangkan dibandingkan dengan kayu yang hanya diawetkan, nilai tersebut meningkat sebesar $26,86 \%$ (dari 64,22 menjadi 81,47 $\mathrm{kg} / \mathrm{cm}^{2}$ ). Nilai keteguhan rekat kayu terdensifikasi yang tinggi mengindikasikan kondisi permukaan kayu yang lebih halus. Kondisi ini terkait dengan keberadaan lignin di permukaan kayu yang dapat berkontribusi pada kekuatan ikatan rekat yang terbentuk, dan sifat glossy lignin. Permukaan kayu yang lebih halus mengakibatkan penurunan luas permukaan yang direkat sehingga akan memperkecil konsumsi perekat. Menurut Bekhta \& Niem (2003) dan Bekhta et al. (2012), vinir yang dipadatkan memiliki permukaan yang lebih halus sehingga mengurangi konsumsi perekat. Menurut Faust \& Borders (1992) dan Dundar et al. (2008), semakin kasar permukaan kayu maka konsumsi perekat akan semakin tinggi, dan sebagai akibatnya akan meningkatkan biaya produksi. Pengaliran lignin ke permukaan kayu dibuktikan oleh warna yang lebih gelap pada kayu-kayu yang terdensifikasi (Gambar 4). Selain akibat lignin, warna gelap permukaan kayu tersebut juga dapat diakibatkan oleh penguapan zat-zat ekstraktif yang volatile akibat panas selama proses pemadatan sebagaimana dinyatakan oleh Korkut et al. (2008).

\section{Penetapan Bahan Baku}

Rekapitulasi AHP (Tabel 7) menunjukkan bahwa kayu terdensifikasi memiliki skor paling tinggi, yaitu sebesar 0,54, sedangkan kayu yang hanya diawetkan memiliki skor yang sama dengan kayu kontrolnya, yakni 0,24.

Dari segi kemudahan dalam pengerjaan, kayu kontrol dan kayu yang hanya diawetkan memiliki skor 0,25 , sedangkan kayu terdensifikasi memiliki skor 0,50 . Kayu kontrol dan kayu yang hanya diawetkan umumnya mudah dikerjakan (dipotong, diserut, diamplas, dibentuk, dan dibor). Kayu terdensifikasi mudah diserut, diamplas, dan dibentuk, tetapi tergolong sedang pada saat dipotong dan dibor. Dari segi penampilan, kayu kontrol dan kayu yang hanya diawetkan juga memiliki skor yang sama, yaitu 0,20, sedangkan skor kayu terdensifikasi mencapai tiga kalinya $(0,60)$. Hasil ini menunjukkan bahwa penampilan kayu terdensifikasi lebih baik dibandingkan dengan kayu kontrol maupun kayu yang hanya diawetkan. Hal ini terlihat dari permukaan kayu yang lebih licin, halus, dan rata dengan lebih sedikit serat berbulu dan serat terangkat, bahkan tidak ditemukan 
adanya serat yang patah. Selain itu, akibat pengempaan, warna kayu yang terdensifikasi menyerupai warna kayu jati tua. Dari segi keteguhan rekat, kayu terdensifikasi memiliki skor yang paling tinggi, yakni 0,43 , sedangkan kayu kontrol dan kayu yang hanya diawetkan memiliki skor yang sama, yakni 0,25 . Dengan demikian, dapat disimpulkan bahwa kayu jati terdensifikasi lebih baik untuk dijadikan bahan baku mebel dan furniture dibandingkan dengan kayu kontrol maupun kayu yang hanya diawetkan.

Bila mempertimbangkan harga kayu, sudah barang tentu kayu yang terpadatkan akan lebih mahal dibandingkan dengan kayu kontrol maupun kayu yang hanya diawetkan (Tabel 8). Harga kayu yang terdensifikasi diperkirakan mencapai dua kali lipat dibandingkan dengan harga kayu kontrol, sedangkan harga kayu yang hanya diawetkan hanya $150 \%$ dari harga kayu kontrol. Meskipun lebih mahal, keuntungan yang akan diperoleh secara keseluruhan akan lebih tinggi karena mutu bahan baku dan mutu produk akan lebih baik sehingga proses produksi akan lebih ekonomis. Di sinilah letak peran para praktisi yang harus bijak dalam memilih bahan baku untuk menghasilkan produk dengan kualitas terbaik sesuai dengan kebutuhan konsumen.

\section{KESIMPULAN}

Densifikasi mampu meningkatkan keragaan sifat dan mutu proses permesinan, serta nilai keteguhan rekat kayu jati cepat tumbuh umur 5 tahun. Kayu terdensifikasi tetap mudah dikerjakan, serat berbulu dan terangkat lebih sedikit, dan tidak memiliki seratserat patah di garis bekas pengerjaan. Penampilan kayu jati terdensifikasi lebih baik, permukaan kayu lebih halus dengan warna yang menyerupai jati tua, sedangkan nilai keteguhan rekatnya meningkat secara signifikan (18,79\% dibandingkan dengan kontrol, dan $26,86 \%$ dibandingkan dengan yang hanya diawetkan). Hasil AHP membuktikan bahwa kayu jati yang terdensifikasi merupakan kayu terbaik sebagai bahan baku industri mebel atau furniture dibandingkan dengan kontrol maupun kayu jati yang hanya diawetkan.

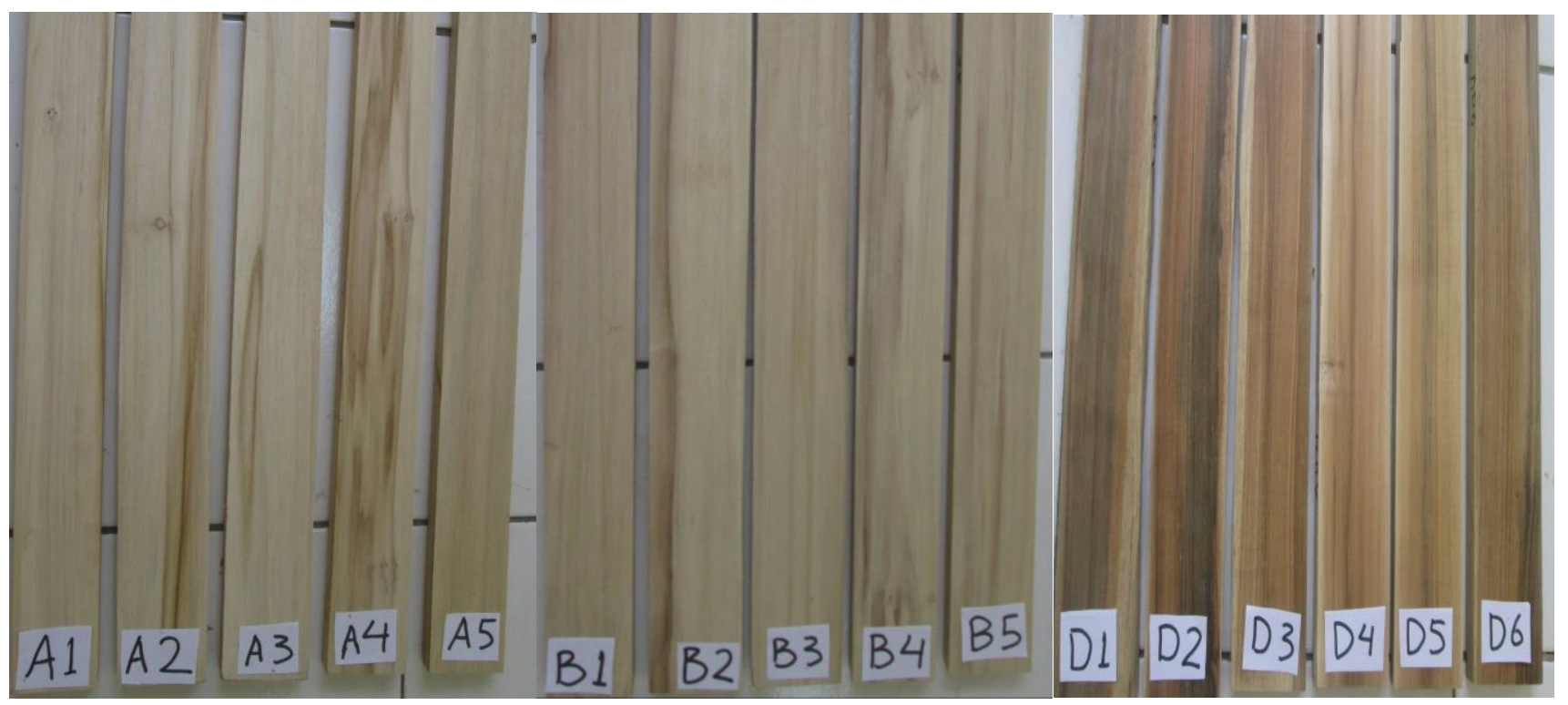

Gambar 4 Perbandingan warna dan tampilan permukaan kayu pada ketiga perlakuan.

Tabel 7 Scoring untuk pemilihan bahan baku berdasarkan analytic hierarchy process (AHP)

\begin{tabular}{lccrr}
\hline \multicolumn{1}{c}{ Perlakuan } & $\begin{array}{c}\text { Kemudahan } \\
\text { dikerjakan }\end{array}$ & Penampilan & Keteguhan rekat & Rata-rata \\
\hline Kontrol & 0,25 & 0,20 & 0,25 & 0,24 \\
Hanya diawetkan & 0,25 & 0,20 & 0,25 & 0,24 \\
Densifikasi (diawetkan dan dipadatkan) & 0,50 & 0,60 & 0,43 & 0,54 \\
\hline
\end{tabular}

Tabel 8 Perbandingan 3 harga kayu pada ketiga perlakuan

\begin{tabular}{lc}
\hline \multicolumn{1}{c}{ Perlakuan } & Persentase perbandingan harga \\
\hline Kontrol & 100 \\
Hanya diawetkan & 150 \\
Densifikasi (diawetkan dan dipadatkan) & 200 \\
\hline
\end{tabular}




\section{DAFTAR PUSTAKA}

Achdiawan R, Puntodewo A. 2011. Livelihood of furniture producers in Jepara. Furniture Value Chain Project Annual Report 2011. Bogor (ID): Center for International Forestry Research.

Amin Y, Dwianto W. 2006. Pengaruh suhu dan tekanan uap air terhadap fiksasi kayu kompresi dengan menggunakan close system compression. Jurnal IImu dan Teknologi Kayu Tropis. 4 (2): 19-24.

[AWPA]. American Wood Preservative Association. 1997. Books of standard. No. A3-77. Granbury: AWPA (US).

Bekhta PA, Niemz P, Sedliacik J. 2012. Effect of prepressing of veneer on the glueability and properties of veneer-based products. European Journal of Wood and Wood Products. 70: 99-106. https://doi.org/10.1007/s00107-010-0486-y

Bekhta PA, Niemz P. 2003. Effect of high temperature on the change in color, dimensional stability and mechanical properties of spruce wood. Holzforschung. 57: 539-546.

Blomberg J, Persson B, Bexell U. 2006. Effects of semi-isostatic densification on anatomy and cellshape recovery on soaking. Holzforschung. 60: 322-331. https://doi.org/10.1515/HF.2006.052

Danuwihardi N. 2015. Kerapatan dan keawetan kayu jati (Tectona grandis L.f.) unggul nusantara terdensifikasi. [Skripsi]. Bogor (ID): Institut Pertanian Bogor.

Dundar T, Ayrilmis N, Candan Z. 2008. Evaluation of surface roughness of laminated veneer lumber (LVL) made from beech veneer treated with various fire retardants and dried at different temperatures. Forest Products Journal. 58: 71-76.

Faust TD, Borders BE. 1992. Using variable glue spread rates to control bond quality and reduce glue consumption in pine plywood production. Forest Products Journal. 42: 49-56.

Hasan H, Tatong B. 2005. Pengaruh pemadatan terhadap sifat fisis dan mekanis kayu Palapi. Media Komunikasi Teknik Sipil. Volume 13. No. 1. Edisi XXXI. Palu (ID): Jurusan Teknik Sipil Fakultas Teknik Universitas Tadulako.

Hill C. 2006. Wood Modification. Chemical, thermal and other process. John Wiley \& Son Ltd. The Atrum,
Southern Gate, Cichester, West Sussex. England (EN).

Inoue M, Nomorito M, Tanahashi M, Rowell RM. 1993. Steam or heat fixation of compressed wood. Wood and Fiber.i25(3): 224-235.

[JAS]. Japanese Agricultural Standard. 2003. Japanese Agricultural Standard for Plywood MAFF Notification No.234-2003.

Korkut DS, Korkut S, Bekar I, Budakçı M, Dilik T, Çakıcıer N. 2008. The effects of heat treatment on the physical properties and surface roughness of Turkish Hazel (Corylus colurna L.) wood. International Journal of Molecular Sciences 9: 1772-1783. https://doi.org/10.3390/ijms9091772

Nestri AP. 2014. Pengaruh densifikasi terhadap sifat fisis dan sifat mekanis kayu jati (Tectona grandis L.f.) Cepat Tumbuh. [Skripsi]. Bogor (ID): Institut Pertanian Bogor.

Saaty TL. 1980. The Analytic Hierarchy Process. McGraw-Hill Book Co. New York (US). https://doi.org/10.21236/ADA214804

Smith DNR, Tamblyin. 1970. Proposed scheme for international standard test for the resistance of timber to impregnation with preservative. Ministry of Technology. Forest Product Research Laboratory. New Zeland. (NZ).

[SNI] Standar Nasional Indonesia. 1999. Pengawetan Kayu untuk Perumahan dan Gedung. Standar No. 03-5010-1. Jakarta (ID): Badan Standarisasi Nasional.

Sulistyono, Nugroho N, Surjokusumo S. 2003. Teknik rekayasa pemadatan kayu II: Sifat fisik dan mekanik kayu Agatis (Agathis lorantifolia Salisb.) terpadatkan dalam konstruksi bangunan kayu. Buletin Keteknikan Pertanian. 17(1): 32-45.

Wahyudi I, T Priadi, IS Rahayu. 2014. Karakteristik dan sifat-sifat dasar kayu Jati Unggul Nusantara umur 4 dan 5 tahun asal Jawa Barat. Jurnal Ilmu Pertanian Indonesia. 19(1): 50-56.

Yovi EY, Nurrochmat DR, Sidiq M. 2013. Domestic market of Jepara's small scale wooden furniture industries: Its potential and barrier. Unpublished project report: Mahagony and Teak furniture: Action research to improve value change efficiency and enhance livelihood (PST/2007/119). Australian Center for International Agricultural Research. Canberra (AU). 